\title{
Integrating Disaster Mitigation Education in The Elementary School Curriculum
}

\author{
Dholina Inang Pambudi \\ Elementary School Teacher Education Department \\ Ahmad Dahlan University \\ Yogyakarta, Indonesia \\ dholinauad@gmail.com
}

\begin{abstract}
The disaster mitigation education aims to impart knowledge and skills in reducing the risk disasters, in other words, it is a preventive measure to reduce the impacts of disasters by building the awareness through education and increasing the capability of facing the disasters with a specific application in science and technology. The disaster mitigation education needs to be given early in order to create a society with disaster awareness.In various conditions, most people are not aware that their occupied areas are prone to disasters. It is presumably due to the lack of socialization of the issues related to disasters either through formal, non-formal and informal. Education should be able to substantially contribute improving the conditions in the community. The strategies of the disaster mitigation education for elementary school students is conducted through the integration of the disaster mitigation education into the curriculum which contains the class activities such as, using media, picture stories, simulations and some multimedia of disaster risk reduction applied in the learning with suitable themes and the developmental stages of elementary school students; and outside the class activities, such as study tour, simulation, mitigation socializations. Creative and innovative approaches are necessary to create a meaningful and fun learning in the integration of mitigation education in order to achieve the learning objectives. It can also give the skills to reduce the disaster risks from the early age in order to create a society with disaster awareness.
\end{abstract}

Keywords- disaster mitigation education, integration, elementary school curriculum

\section{INTRODUCTION}

Based on the history, natural disasters that have occurred in Indonesia include earthquakes, tsunamis, volcanic eruptions, floods, landslides, storms, and drought. It can be said that Indonesia is a country that has a very high potential for disasters [1].

The disaster mitigation education should be given start from the early age to create a society with disaster awareness, as it can be referred that Indonesia is the junction of three major plates of the world. Those three active plates are the Indo-Australian plate in the southern part, the Eurasian plate in the northern part and the Pacific plate in the eastern part. The plates move and collide with each other so that the IndoAustralian plate crash under the Eurasian plate.The subduction of the Indo-Australian plate which moves northward and the Eurasian plate which moves southward raises a lane of earthquakes and a series of active volcanoes. Mister and Jordan (1978) also explain that the Southeast Asia moves $1 \mathrm{~cm} /$ year to the southeast, while the Indo-Australian plate moves $7 \mathrm{~cm} /$ year to the north and the Pacific plate moves $9 \mathrm{~cm} /$ year to the west. There are so many data show the movements of those plates which has been acquired since the appearance of Global Positioning System (GPS) [2].

Mentioned by "Badan Penanggulangan Bencana Daerah" (BPBD) DIY, there are about 3,000 schools in the province which are located in the disaster-prone areas and still need some additional socializations of disaster at every level ranging from elementary schools to colleges. The disaster mitigation impartial in the beginning of the school can be done with an easy simulation exercises, and it is included in the school curriculum in which the disaster mitigation is included in the suitable material [3]. Thus, it becomes a strong foundation for developing the appropriate learning about the disasters for elementary students to be able to understand the disaster education from the early age.

The provision of education by the educational institutions or schools should not only provide the transfer of knowledge but also be able to provide competences and skills for survival. The disaster mitigation is a part of the survival skills for students. Students are the fastest media to transfer knowledge gained from school to their families and communities. Therefore, the empowerment of students of elementary schools to understand the disaster mitigation/disaster risk reduction is the first step in building the disaster awareness in the community.

\section{DISCUSSION}

\section{A. Disaster Mitigation}

Disaster mitigation is defined as the attempts to reduce the disaster risks [4]. Moreover, the disaster mitigation is also defined as the efforts to reduce the impacts of disasters both natural disasters and man-made disasters or a combination of both causes in a country or society [1]. The disaster mitigation is also defined as further actions to reduce or eliminate longterm risks to life and properties. The disaster mitigation is a preventive measure to reduce the impacts of disasters by building the awareness through education and increasing the capability of facing the disasters with a specific application in science and technology [5].

Based on the theories and concepts, there are several stages of emergency management: prevention, preparedness, response, and rehabilitation reconstruction phase [1]. It can be concluded that the disaster mitigation is in the first stage, 
therefore, it is very potential to design and apply the effective programs to reduce the disaster risks in any places in Indonesia according to the local conditions.

Disaster mitigation management is very important in order to build an integrated system to reduce the impacts of disasters through awareness and improve their awareness of disasters in accordance with local conditions. The awareness and the capacity improvement through the formal ways can be conducted by integrating the disaster mitigation education in schools. The disaster mitigation education is a part of the educational performance, which is a responsibilty of the three kinds of education which are formal, informal and non-formal education. The three basic education centers; families, schools and communities have great potential in helping the students to disseminate the disaster awareness from the early age since Indonesia is considered as a disaster-prone area.

The further expectation from the preventive strategy implementation to the disasters through the disaster mitigation is to create a society which is aware, safe and peaceful. To achieve this goal, the efforts should be continual, because the disaster mitigation education should be done through formal, informal and non-formal education. In the elementary level, especially for the students in their golden ages. Their golden ages determine the individual development, in this case, the awareness about disaster mitigation education from the early age. The success of this disaster mitigation education in elementary schools and will generally determine an individual's ability in the future. This shows how crucial the effective disaster mitigation education can be. Therefore, this education should be designed and developed sustainably mainly in elementary schools.
The approach used in the implementation of the 2013 curriculum primarily in elementary schools is an integrated thematic. To integrate the Basic Competence of various subjects, the intradisiplinary, interdisciplinary, multidisciplinary and transdisciplinary should be conducted [6].

Integrated intradisiplinary combines the attitude, knowledge and skills dimensions into a comprehensive subject. Interdisciplinary integration is done by combining the basic competencies of several subjects which are related to one another in order to avoid overlapping and maintain the suitability in the learning. Integration is done without incorporating the basic competencies of the multidisciplinary for each subject so that each subject still had their basic right competencies. Integrated transdisciplinary is done by connecting various subjects with the problems encountered in the vicinity so that the learning process becomes contextual. Themes are the connector of various basic concepts so that students will not learn the basic concepts partially. Thus, learning gives full meaning to students as reflected in a variety of themes available.

Integrated thematic is defined as a process of integration of intra, inter, multi and trans-disciplinary as described above. If it is studied in a thematic learning, the subject includes themes and also educational materials related to disaster mitigation. Therefore, teachers should be critical in understanding the theme which will be taught and be able to choose the right theme to be inserted by disaster mitigation theme. Here are the learning themes for the Elementary School students Grade $1-6$ :

\section{B. Integrated Thematic in the Elementary School Curriculum}

TABLE I. LEARNING THEMES FOR THE ELEMENT ARY SCHOOL STUDENT GRADE I-III

\begin{tabular}{|l|l|l|}
\hline \multicolumn{1}{|c|}{ Themes for GRADE I } & \multicolumn{1}{|c|}{ Themes for GRADE II } & \multicolumn{1}{c|}{ Themes for Grade III } \\
\hline Diriku & Hidup rukun & $\begin{array}{l}\text { Perkembangbiakan } \\
\text { tumbuhan }\end{array}$ \\
\hline Kegemaranku & Bermain di lingkunganku & Perkembangan teknologi \\
\hline Kegiatanku & Tugasku sehari-hari & Perubahan di alam \\
\hline Keluargaku & Aku dan sekolahku & Peduli lingkungan \\
\hline Pengalamanku & Hidup bersih dan sehat & Permainan tradisional \\
\hline Lingkungan bersih, sehat, dan asri & Air, bumi, dan matahari & Indahnya persahabatan \\
\hline Benda, hewan, dan tanaman di sekitarku & Merawat hewan dan tumbuhan & Energi dan perubahannya \\
\hline Peristiwa alam & Keselamatan di rumah dan perjalanan & Bumi dan alam semesta \\
\hline
\end{tabular}

TABLE II. LEARNING THEMES FOR THE ELEMENTARY SCHOOL SSTUDENT GRADE IV-VI

\begin{tabular}{|l|l|l|}
\hline \multicolumn{1}{|c|}{ Themes for GRADE IV } & \multicolumn{1}{|c|}{ Themes for GRADE V } & \multicolumn{1}{|c|}{ Themes for GRADE VI } \\
\hline Indahnya kebersamaan & Benda-benda di lingkungan sekitar & Selamatkan makhluk hidup \\
\hline Selalu berhemat energi & Peristiwa dalam kehidupan & Persatuan dalam perbedaan \\
\hline Peduli terhadap lingkungan hidup & Kerukunan dalam bermasyarakat & Tokoh dan penemu \\
\hline Berbagai pekerjaan & Sehat itu penting & Globalisasi \\
\hline Pahlawanku & Bangga sebagai bangsa Indonesia & Wirausaha \\
\hline Indahnya negeriku & Organ tubuh manusia dan hewan & Kesehatan masyarakat \\
\hline Cita-citaku & Sejarah peradaban Indonesia & Organisasi di sekitarku \\
\hline Tempat tinggalku & Ekosistem & Bumiku \\
\hline Makananku sehat dan bergizi & Lingkungan sahabat kita & Menjelajah angkasa luar \\
\hline
\end{tabular}

Teachers can include disaster mitigation materials into various themes with learning creativities, the creative learning method. Teachers' creativity in planning the learning process should be grounded with a high commitment in implementing the disaster mitigation education in classes. Elementary school teachers must have an understanding of the effective, creative 
and fun learning strategies, accordance with the level of development of the elementary school students both in lower grades and higher grades. Those various kinds of principles should be considered in designing the teaching-learning inside and outside the classroom. Learning activities should follow the following principles: 1) students are facilitated to find out; 2) students learn from a variety of learning resources; 3) the learning processes use the scientific approach; 4) competencybased learning; 5) integrated learning;6) learning processes that emphasize divergent answers that have multi-dimensional truths;7) applicable skill-based learning;8) the improvement of equilibrium, continuity and the relation between science and skills; 9) learning that promotes acculturation and students' empowerement as lifelong learners;10) learning applied values to provide exemplary (ing ngarso sung tulodo), building willingness (ing madyo Mangun Karso), and developing the creativity of learners in the learning process (tut wuri handayani);11) learning are held at homes, schools and communities;12) the usage of information and communication technologies to improve the efficiency and effectiveness of learning;13) recognition of individual differences and cultural background of learners; and14) fun and challenging learning environment [7].
The learning principles as the implementation of curriculum require high creativity of the teachers. Likewise, related to the desired disaster mitigation education, it can be done through theme-by-theme activities that have been applied. Several issues related to the development of integrated disaster mitigation education in the elementary school curriculum. Identification of variety strategies of disasters mitigation education that will be used, for example:

1. Being a part of the learning which is compatible with the theme in the class. In this case, teachers can perform some analysis on students'and teachers' books to give strength the disaster mitigation education for students through creative strategies.

2. Activities outside the classroom, for example: (a) Programmed activities include: disaster simulations, study tours (visiting volcano, activity and mitigation socializationsfrom BNPB, BPDB, extra-curricular activities (Scout and little cops). (b) Spontaneous activities, there are no scheduled activities such as taking out the trash into its place.

The following table shows the examples of activities related to disaster mitigation education which is integrated into the elementary school curriculum that can be developed and combined with certain themes as follows: 
TABLE III. SUITABLE THEMES AND LEARNING METHODS

\begin{tabular}{|l|l|}
\hline \multicolumn{1}{|c|}{ Themes } & \multicolumn{1}{c|}{ Methods } \\
\hline Peristiwa Alam & Picture story \\
& Video \\
& Comics \\
& Gaming Simulation \\
& Multimedia disaster mitigation \\
\hline Perubahan di Alam & Picture story \\
& Video \\
& Comics \\
& Multimedia disaster mitigation \\
\hline Peduli Lingkungan & Picture story \\
& Video \\
& Comics \\
\hline Bumi dan Alam semesta & Multimedia disaster mitigation \\
& Picture story \\
& Video \\
\hline Lingkungan sahabat kita & Comics \\
& Picture story \\
& Video \\
& Comics \\
\hline Bumiku & Multimedia disaster mitigation \\
& Picture story \\
& Video \\
\hline
\end{tabular}

\section{CONCLUSION}

In various conditions that occur in the community show that most people are not aware that the occupied areas are categorized into disaster-prone areas. It is presumably due to the lack of socialization of the issues related to disaster either through formal, non-formal and informal. The community would come to an understanding and realization that their occupied areas are prone to disasters only after a disaster happens and it takes casualties in property, objects, and souls. Of course, this situation should not be allowed to drag on. Education should be able to substantially contribute improving the conditions in the community. The early childhood education and elementary schools underline the foundation of the disaster mitigation education for further development in order to create a society with disaster awareness. Therefore, it requires a strategy that allows the disaster mitigation education in the elementary schools to be able to work effectively.

The disaster mitigation education strategies for elementary students is conducted through the integration of the disaster mitigation education into the curriculum, such as using media picture stories, simulations and some multimedia of disaster risk reduction applied in the learning with a suitable theme and the developmental stages of elementary students. Creative and innovative approaches are necessary to create a meaningful and fun learning in the integration of mitigation education in order to achieve the learning objectives. It can also give the skills to reduce the disaster risks from the early age in order to create a society with disaster awareness.

\section{REFERENCES}

[1] LIPI, Panduan penyusunan kontijensi planing \& prosedur tetap kesiapsiagaan bencana gempa bumi dan tsunami, Jakarta: Compress. Hlm $1,2,9,2008$

[2] H. Verstappen, Outline of the geomorphology of Indonesia. Netherland: International Institute for Aeropsace Survey and Earth Science. 2000 pp 1

[3] Kedaulatan Rakyat, Mitigasi Bencana oleh Badan Penanggulangan Bencana Daerah" (BPBD) DIY, 1 February 2014

[4] D. Suhardjo, Arti penting pendidikan mitigasi bencana dalam mengurangi risiko bencana. Cakrawala Pendidikan, 2011, pp174-188.

[5] A.B. Susanto. Disaster management di negeri rawan bencana. Jakarta:The Jakarta Consulting Grup. 2006. pp. 25

[6] Permendikbud. No 57 about Kurikulum 2013 Sekolah Dasar/Madrasah Ibtidaiyah, 2014

[7] Permendikbud. No 103 tentang Pembelajaran Pada Pendidikan Dasar Dan Pendidikan Menengah, 2014 